\title{
Ectopic Cushing' syndrome caused by a neuroendocrine carcinoma of the mesentery
}

\author{
Mathias Fasshauer ${ }^{\dagger 1}$, Thomas Lincke ${ }^{\dagger 2}$, Helmut Witzigmann ${ }^{3}$, Regine Kluge ${ }^{2}$, \\ Andrea Tannapfel ${ }^{4}$, Michael Moche ${ }^{5}$, Michael Buchfelder ${ }^{6}$, \\ Stephan Petersenn ${ }^{7}$, Juergen Kratzsch ${ }^{8}$, Ralf Paschke ${ }^{1}$ and \\ Christian A Koch*1,9
}

\begin{abstract}
Address: ${ }^{1}$ Division of Endocrinology and Nephrology, University of Leipzig, Philipp-Rosenthalstr. 27, 04103 Leipzig, Germany, ${ }^{2}$ Department of Nuclear Medicine, University of Leipzig, Liebigstr., 04103 Leipzig, Germany, ${ }^{3}$ Department of Surgery, University of Leipzig, Liebigstr., 04103 Leipzig, Germany, ${ }^{4}$ Institute of Pathology, Ruhr-Universität Bochum an den BG Kliniken Bergmannsheil, Bürkle-de-la-Camp-Platz 1, 44789 Bochum, Germany, ${ }^{5}$ Department of Radiology, University of Leipzig, Liebigstr., 04103 Leipzig, Germany, ${ }^{6}$ Department of Neurosurgery, FriedrichAlexander University of Erlangen-Nuremberg, Schwabachanlage, Erlangen, Germany, ${ }^{7}$ Division of Endocrinology, Universität Duisburg-Essen, Hufelandstr. 55, 45122 Essen, Germany, ${ }^{8}$ Institute of Laboratory Medicine, Clinical Chemistry, and Molecular Diagnostics, University of Leipzig, Paul-List-Str., 04103 Leipzig, Germany and ${ }^{9}$ Division of Endocrinology, University of Mississippi Medical Center, 2500 N State Str, Jackson, MS 39216, USA

Email: Mathias Fasshauer - mathias.fasshauer@medizin.uni-leipzig.de; Thomas Lincke - thomas.lincke@medizin.uni-leipzig.de; Helmut Witzigmann - helmut.witzigmann@medizin.uni-leipzig.de; Regine Kluge - regine.kluge@medizin.uni-leipzig.de; Andrea Tannapfel - andrea.tannapfel@rub.de; Michael Moche - michael.moche@medizin.uni-leipzig.de; Michael Buchfelder - michael.buchfelder@nch.imed.uni-erlangen.de; Stephan Petersenn - stephan.petersenn@uni-essen.de; Juergen Kratzsch - juergen.kratzsch@medizin.uni-leipzig.de; Ralf Paschke - ralf.paschke@medizin.uni-leipzig.de; Christian A Koch* - ckoch@medicine.umsmed.edu

* Corresponding author †Equal contributors
\end{abstract}

Published: 27 April 2006

BMC Cancer2006, 6:108 doi:10.1186/147/-2407-6-108
Received: 09 March 2006

Accepted: 27 April 2006

This article is available from: http://www.biomedcentral.com/I47I-2407/6/108

(c) 2006Fasshauer et al; licensee BioMed Central Ltd.

This is an Open Access article distributed under the terms of the Creative Commons Attribution License (http://creativecommons.org/licenses/by/2.0), which permits unrestricted use, distribution, and reproduction in any medium, provided the original work is properly cited.

\begin{abstract}
Background: ACTH overproduction within the pituitary gland or ectopically leads to hypercortisolism. Here, we report the first case of Cushing' syndrome caused by an ectopic ACTHsecreting neuroendocrine carcinoma of the mesentery. Moreover, diagnostic procedures and pitfalls associated with ectopic ACTH-secreting tumors are demonstrated and discussed.

Case presentation: A $4 \mathrm{I}$ year-old man presented with clinical features and biochemical tests suggestive of ectopic Cushing's syndrome. First, subtotal thyroidectomy was performed without remission of hypercortisolism, because an octreotide scan showed increased activity in the left thyroid gland and an ultrasound revealed nodules in both thyroid lobes one of which was autonomous. In addition, the patient had a $3 \mathrm{~mm}$ hypoenhancing lesion of the neurohypophysis and a $\mathrm{I} \mathrm{cm}$ large adrenal tumor. Surgical removal of the pituitary lesion within the posterior lobe did not improve hypercortisolism and we continued to treat the patient with metyrapone to block cortisol production. At 18-months follow-up from initial presentation, we detected an ACTHproducing neuroendocrine carcinoma of the mesentery by using a combination of octreotide scan, computed tomography scan, and positron emission tomography. Intraoperatively, use of a gamma probe after administration of radiolabeled IIIIn-pentetreotide helped identify the mesenteric neuroendocrine tumor. After removal of this carcinoma, the patient improved clinically.
\end{abstract}


Laboratory testing confirmed remission of hypercortisolism. An octreotide scan 7 months after surgery showed normal results.

Conclusion: This case underscores the diagnostic challenge in identifying an ectopic ACTHproducing tumor and the pluripotency of cells, in this case of mesenteric cells that can start producing and secreting ACTH. It thereby helps elucidate the pathogenesis of neuroendocrine tumors. This case also suggests that patients with ectopic Cushing's syndrome and an octreotide scan positive in atypical locations may benefit from explorative radioguided surgery using $1 / 1 \mathrm{ln}$ pentetreotide and a gamma probe.

\section{Background}

Endocrine tumors can develop from a variety of tissue types and are often under- or misdiagnosed which underscores the difficulties to classify them. Ectopic ACTH overproduction not only leads to hypercortisolism but is also associated with various diagnostic and therapeutic pitfalls despite performing extensive diagnostic procedures.

\section{Case presentation}

In September 2003, a 41-year-old man presented with unexplained progressive weight gain, facial plethora, tremor, sweating, newly-diagnosed hypertension, hypokalemia, and diabetes mellitus. Physical examination revealed a blood pressure of $170 / 110 \mathrm{~mm} \mathrm{Hg}$, pulse of $88 \mathrm{bpm}$, thyroid enlargement, and cushingoid features including striae, moon face, central obesity, and a buffalo hump. Laboratory testing showed hyperthyroidism (undetectable TSH, free T4 of $32 \mathrm{pmol} / \mathrm{L}$ (normal: $12-$ 22), free $\mathrm{T} 3$ of $9 \mathrm{pmol} / \mathrm{L}$ (normal: 3.95-6.80)) and increased $24 \mathrm{~h}$ urinary free cortisol $(7579 \mathrm{nmol}$ per day, normal range: 22-212). Thyroid ultrasound showed a multinodular goiter. A Tc-99m-pertechnetate thyroid scan revealed increased uptake in an area of the left thyroid gland corresponding to an autonomous adenoma. Serum calcitonin was within the normal range. Basal serum cortisol and plasma ACTH were significantly elevated at 1307 nmol/l (normal range: 187-724) and $22.51 \mathrm{pmol} / \mathrm{l}$ (1.98-11.4), respectively. After a 2-mg overnight dexamethasone suppression test, serum cortisol was still at 1132 $\mathrm{nmol} / \mathrm{l}$ (normal, < 80). Midnight cortisol was elevated at $847 \mathrm{nmol} / \mathrm{l}$. After an overnight 8-mg dexamethasone suppression test, serum cortisol decreased by $38 \%$ of basal values suggesting ectopic ACTH-secretion (EAS). CRH stimulated serum cortisol and plasma ACTH to less than $4 \%$ of basal values. Inferior petrosal sinus sampling (IPSS) did not show significant central-to-peripheral ACTH gradients. Ectopic ACTH syndrome was diagnosed. Computed tomography (CT) scans at first presentation did not show pulmonary and/or abdominal tumors, however, both adrenals appeared enlarged with the left gland showing a tumor of $1 \mathrm{~cm}$ size. A magnetic resonance imaging (MRI) scan of the head demonstrated a small 3 mm hypointense and hypoenhancing lesion of the neurohypophysis (Fig. 1). An ${ }^{111}$ In-pentetreotide scan showed radiotracer enrichment in the left thyroid gland consistent with the region of the autonomous adenoma and faint focal octreotide enhancement in the abdomen which was interpreted to be nonspecific because of lacking correlation on CT scan and changing location of enhancement between early and late scan (Fig. 2). Positron emission tomography (PET) with ${ }^{18} \mathrm{~F}$ - fluorodeoxyglucose (FDG) and colonoscopy showed normal results. Thyroid antibodies were negative, supporting the scintigraphic finding that hyperthyroidism in this patient was caused by an autonomous adenoma. Given the scenario of EAS and an octreoscan being reliably positive only in the left thyroid gland, we decided to perform a left-sided hemithyroidectomy and subtotal resection of the right gland after treatment with methimazole, although basal calcitonin was normal and pentagastrin stimulation could not be performed because it was not available. Extensive pathological workup of the thyroid specimen did not reveal an ACTH-producing endocrine tumor but a $2 \mathrm{~mm}$ sized benign nodule on the right side, and 2 benign nodules ( 1

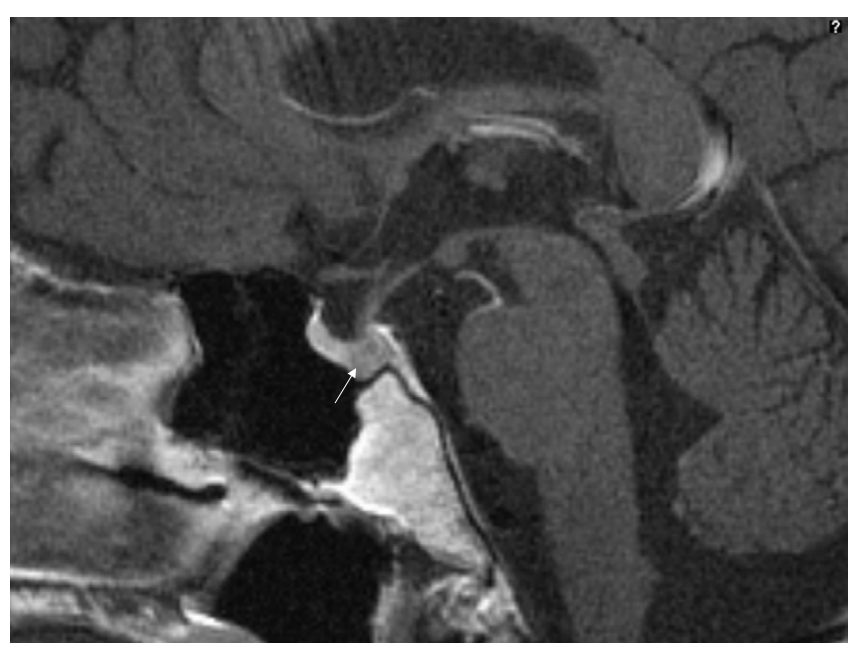

Figure I

TI-weighted gadolinium-enhanced MRI of the pituitary. A hypointense lesion of the neurohypophysis is indicated. 


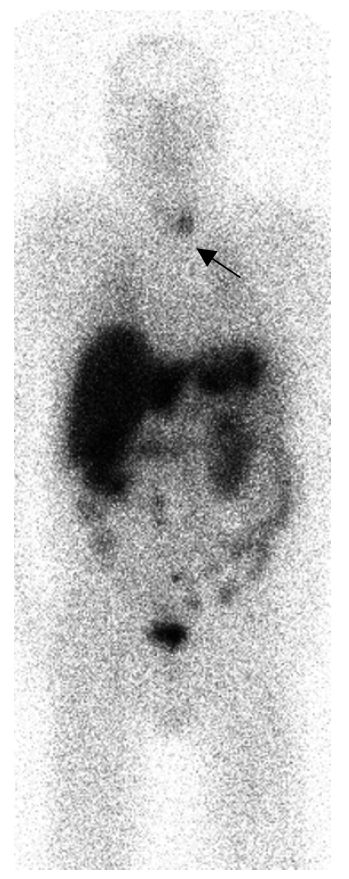

$10 / 2003$

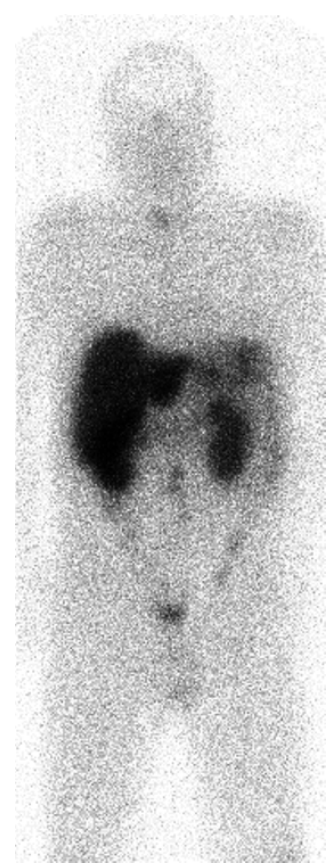

$01 / 2004$

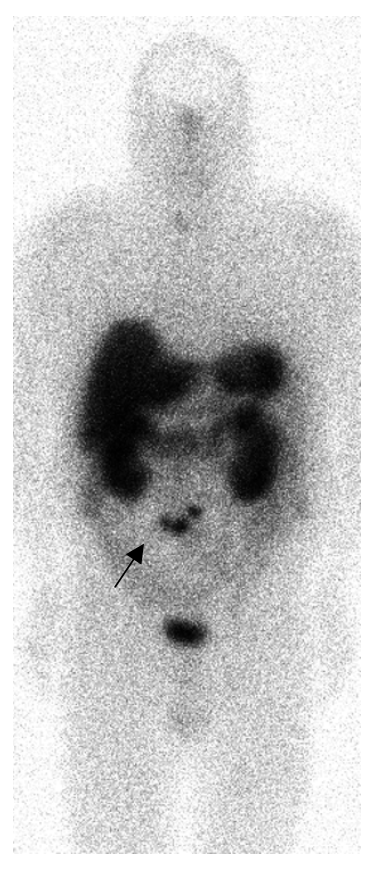

$04 / 2005$

\section{Klinik für Nuklearmedizin, Universität Leipzig}

\section{Figure 2}

IIIIn-pentetreotide scintigraphy. Radiotracer accumulation in the left thyroid in 10/2003 (arrow). The mesenterial neuroendocrine tumor became clearly visible in 4/2005 (arrow).

$\mathrm{cm}$ and $2 \mathrm{~cm}$ in diameter, respectively) within the left thyroid gland.

Whereas hyperthyroidism improved rapidly, hypercortisolism persisted. Because the patient had elevated liver function tests, thereby limiting the use of ketoconazole, we began metyrapone $(2.5 \mathrm{~g} / \mathrm{d}$ divided into $750 \mathrm{mg}$ in the morning and at noon, and $1 \mathrm{~g}$ in the evening to perform medical adrenalectomy) combined with hydrocortisone replacement $(10 \mathrm{mg}$ in the morning at at noon, and $5 \mathrm{mg}$ in the evening) to achieve normal $24 \mathrm{~h}$ urinary cortisol values. Regular follow-up examinations at 3, 6, 9, and 12 months after initial presentation confirmed the pituitary lesion within the posterior lobe, while CT scans of thorax and abdomen remained negative except for the left-sided adrenal tumor. $24 \mathrm{~h}$ urinary catecholamines including fractionated metanephrines were negative. Over the fol- lowing months, control of hypercortisolism by metyrapone became difficult and the question arose whether bilateral adrenalectomy should be performed. Therefore, we consulted a neuropathologist/pathologist (A.O.V.) and neurosurgeon (E.H.O.) at the National Institutes of Health whether they ever had seen an ACTH-producing pituitary adenoma located in the posterior lobe (see ref. 1). Subsequently, transsphenoidal surgery was performed to explore the pituitary lesion in our patient. Despite complete removal of this lesion, hypercortisolism persisted and metyrapone therapy was continued. Histological workup of the removed pituitary tissue revealed normal posterior pituitary. Postoperatively, diabetes insipidus developed and persisted. An extensive re-evaluation was performed 18 months after initial presentation. An octreoscan revealed tracer accumulation in projection of the upper and middle part of the right abdomen (Fig. 2). 


\section{CT scans of the abdomen}

$04 / 2005$

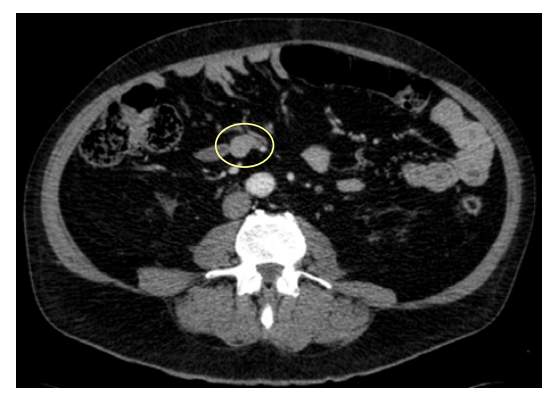

$01 / 2004$

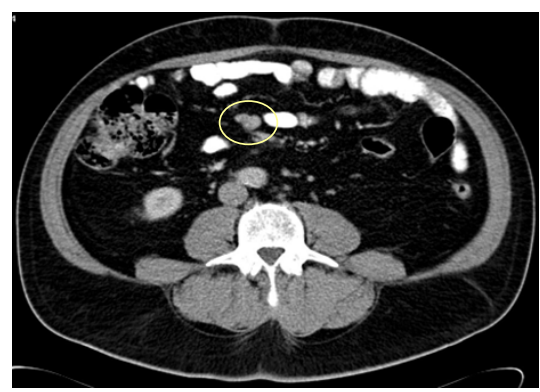

$09 / 2003$

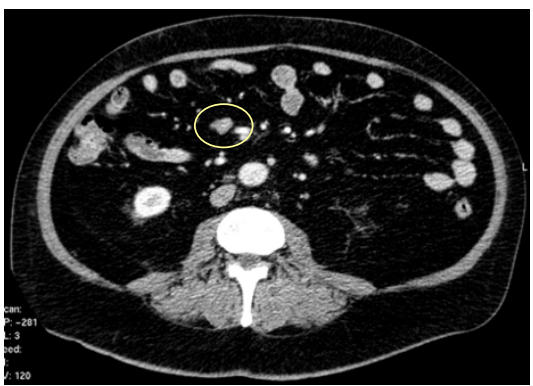

MRI, T1, fat-saturated

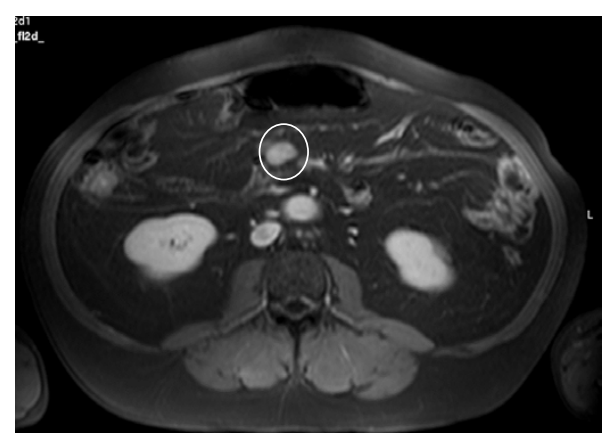

MRI, T1, before and after gadolinium

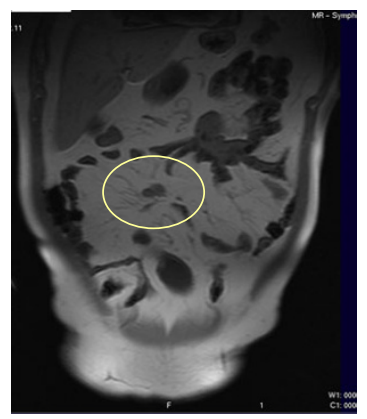

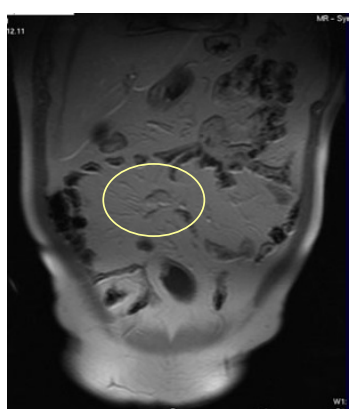

\section{Figure 3}

CT and MRI scans of the abdomen. In 4/2005, a mass (circle) is shown which has also been there in earlier scans but had been interpreted as normal intestine. Fat-saturated and TI-weighted MRI scanning after gadolinium shows a mass in the mesentery outside the intestine.

Additional ${ }^{18}$ F-FDG PET showed increased glucose metabolism of this abdominal area. In accordance with these findings, a $21 \times 15 \mathrm{~mm}$ tumor mass was demonstrated on CT and MRI scans in this region (Fig. 3). In retrospect, this tumor could also be seen in earlier CT scans but had been interpreted as normal intestine because of smaller size, atypical location for an ACTH-producing tumor, and only moderate uptake on octreotide scans. We decided to perform an explorative laparotomy. Before surgery, ${ }^{111}$ Inpentetreotide was administered to support tumor localization during surgery with a gamma counter and facilitate maximal tumor removal (Fig. 4). After the abdominal wall had been opened, the neuroendocrine tumor was instantly visible (Fig. 5). Because this lesion had been initially assumed to be metastatic tissue of a primary neuroendocrine tumor and a multifocal appearance of the abdominal ${ }^{111}$ In-pentetreotide enhancement, the gamma probe was used to detect further tumor tissue (Fig. 6). Histopathological and immunohistochemical analyses of the removed tissue revealed a well-differentiated neuroendocrine carcinoma of the mesentery with strong expression of ACTH (Fig. 7). The tumor also strongly expressed NSE, chromogranin A, and synaptophysin. The MIB-1 proliferation index was approximately $1 \%$. Immunohistochemical analyses for the expression of somatostatin receptors type 1 to 5 were negative. All removed lymph nodes were tumor-negative but also showed increased activity by the gamma probe during surgery.

Follow-up at four weeks and at 4 (7) months after surgery showed a normal $2 \mathrm{mg}$ dexamethasone suppression test and $24 \mathrm{~h}$ urinary cortisol levels. Plasma ACTH levels were normal (4.9 and $5.2 \mathrm{pmol} / \mathrm{L}$, normal: 1.8-12.8). NSE was $10.7 \mathrm{ng} / \mathrm{ml}$ (normal, < 13), chromogranin A and calci- 


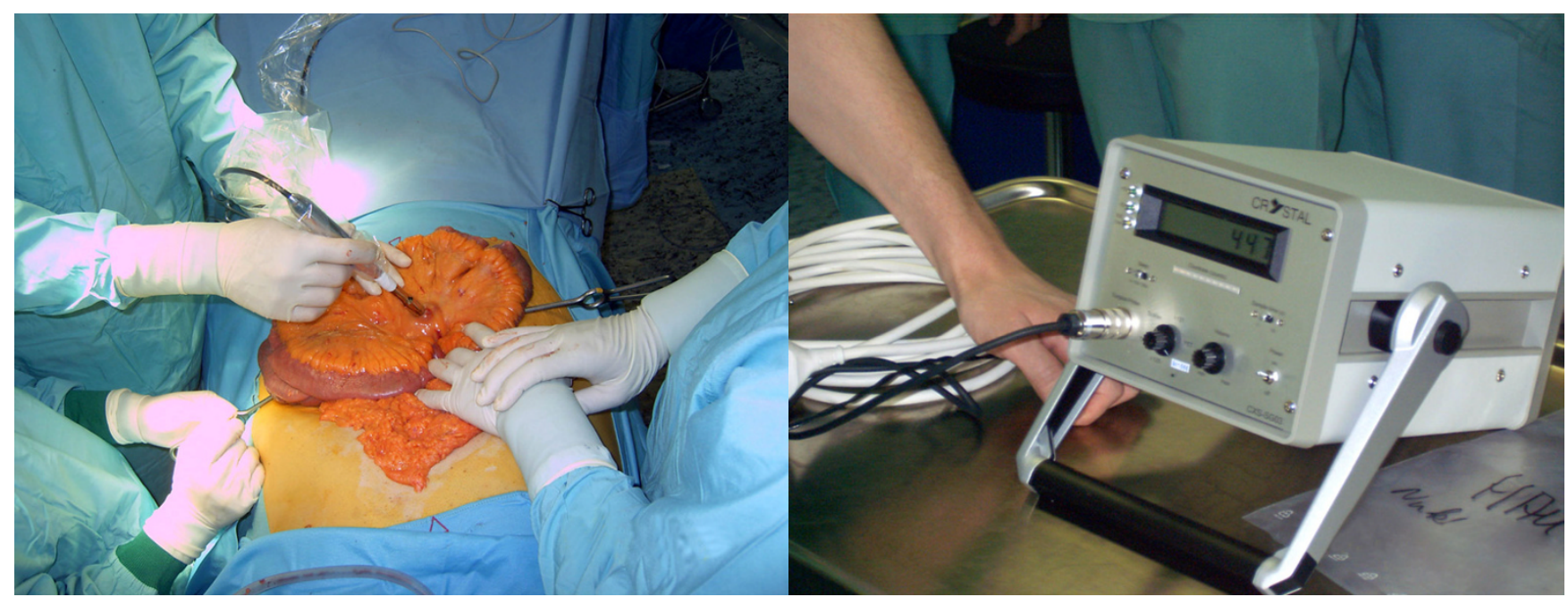

Figure 4

Gamma probe used intraoperatively.

tonin were undetectable. In addition, the insulin requirement to treat the patient's type 2 diabetes declined by more than $50 \%$. At 7 month follow-up, the patient had regained strength and muscle mass, did not need further potassium replacement, and felt fine. An octreoscan showed normal results.

\section{Discussion}

We present for the first time a case of EAS caused by a neuroendocrine carcinoma of the mesentery. Among ectopic ACTH-producing lesions, approximately 50\% originate from intrathoracic tumors, usually small cell carcinomas [2-6]. Other well-described tumors of ectopic ACTH-production include medullary thyroid carcinoma, pheochromocytoma, as well as carcinomas of the thymus and pancreas [2,7-11]. Except for the pancreas, other organs and locations for ACTH-producing tumors in the abdomen, i.e. appendix, duodenum, ileum, colon, anal canal, uterine cervix, and ovary are uncommon [12-20]. Endocrine tumors can develop from a variety of tissue types and are often under- or misdiagnosed which underscores the difficulties to classify them [21]. Endocrine tumors may or may not produce and/or secrete hormones [2232]. Mesenchymal tumors such as solitary fibrous tumors of the pleura, for instance, can lead to tumor hypoglycemia through production and secretion of pro-IGF-II [Fasshauer and Koch, unpublished observation; [33,34]]. This ability of tumor cells making hormones is not surprising, if one considers the embryologic origin of tissues. For instance, upon induction, ectoderm of the blastula differentiates into mesodermal tissue such as chorda, muscle, and fibrous tissue. Without induction, however, ectoderm will differentiate into epidermis-like epithelium [35]. Arita-Melzer et al. [24] reported a 76-yo man who suffered from Cushing's syndrome caused by ectopic ACTH production of a sacrococcygeal chordoma. In our patient, we propose that cells of the mesentery became malignant and started to produce ACTH ectopically. Although all removed lymph nodes were negative for tumor and the patient postoperatively became and remained eucortisolemic at 7 month follow-up, there is still a small chance that he harbors somewhere else a primary endocrine tumor producing ACTH that had metastasized to the mesentery. Another atypical location for primary endocrine tumors that had been controversially discussed for a long time is the liver. Maire et al. [36] has recently shown that this organ can harbor primary endocrine tumors, although the histogenesis of these tumors remains unknown. One hypothesis claims that pluripotent stem cells in the liver lead to primary endocrine tumors, a theory that is supported by a study showing that rat hepatic stem cells can differentiate into pancreatic functional endocrine cells [37]. Another hypothesis assumes that these liver tumor cells are of neuroectodermal origin. In our patient, no liver lesions were seen. Primary endocrine tumors have also been reported in lymph nodes [38]. In our patient, however, the removed tumor tissue and lymph nodes did not demonstrate evidence for lymph nodes as an origin of tumor growth.

Diagnosing EAS is often difficult [39,40]. None of the dynamic biochemical tests achieves $100 \%$ accuracy, although BIPSS almost always shows an absent central gradient [41]. A recent report by Ilias and co-workers emphasizes that $21 \%$ and $26 \%$ of patients with EAS have false-positive responses to dexamethasone and/or CRH [6]. In their hands, IPSS is the single best test for EAS that correctly identified 66 out of 67 patients [6]. In our case, 


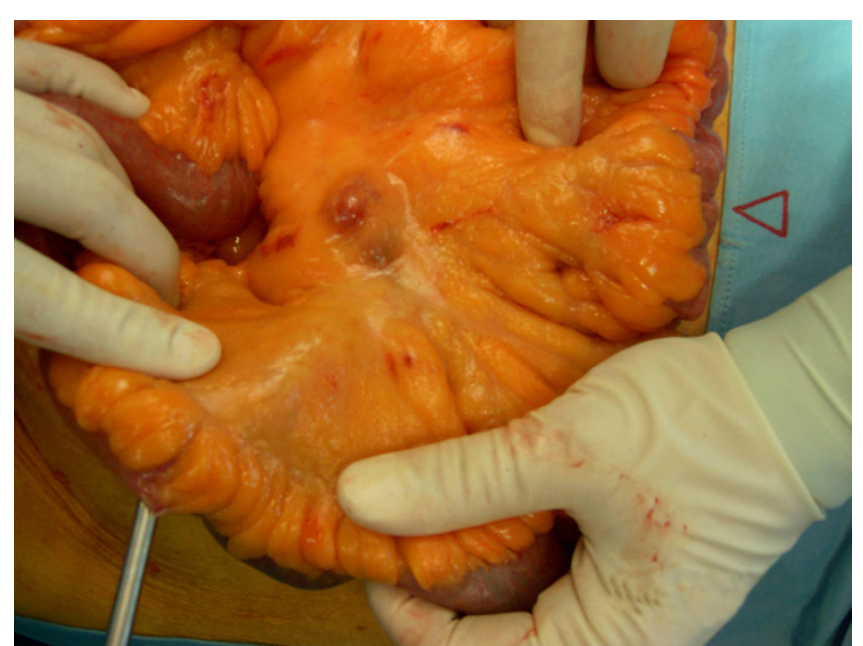

Figure 5

Intraoperative situs. A brown tumor mass is visible within the yellow mesentery.

all three independent tests suggested EAS, since a) the decline of serum cortisol was less than $50 \%$ in the overnight 8-mg dexamethasone suppression test as compared to basal values, b) the increase in serum cortisol and plasma ACTH was less than $20 \%$ and $35 \%$, respectively, after CRH stimulation, and c) IPSS demonstrated a less than 2-fold central-to-peripheral ACTH gradient basal and less than 3-fold gradient after CRH administration.

However, in the case presented, correct localization of tumor causing the EAS had been difficult. The percentage of tumors not identified despite extensive evaluation is between $12 \%$ and $19 \%[5,6,42]$. In our case, imaging studies consisted of CT scans of chest, abdomen, and pelvis, an MRI scan of the pituitary, octreotide scans, and ${ }^{18} \mathrm{~F}-$ FDG PET at initial presentation and during follow-up. Except for PET, these tests are commonly used to locate the cause of EAS [2,39,43-47]. Furthermore, octreotide has been suggested not only as a diagnostic tool but also as second-line therapy in some cases of EAS $[48,49]$. PET is a second-line diagnostic procedure when CT scan, MRI, and octreotide scan do not locate the cause of EAS [45]. In the case presented, only the octreotide scan and the MRI of the pituitary had yielded pathological results at first presentation. Since EAS has been described in medullary thyroid carcinoma and the patient had multinodular goiter in association with hyperthyroidism, subtotal thyroidectomy was performed with the intention to exclude medullary thyroid carcinoma and resect the proven autonomous adenoma simultaneously in the face of a normal basal calcitonin and lacking pentagastrin stimulated calcitonin $[8,10]$. However, this surgical procedure did not improve EAS. This result supports recent findings by Becker and co-workers that false-positive octreotide

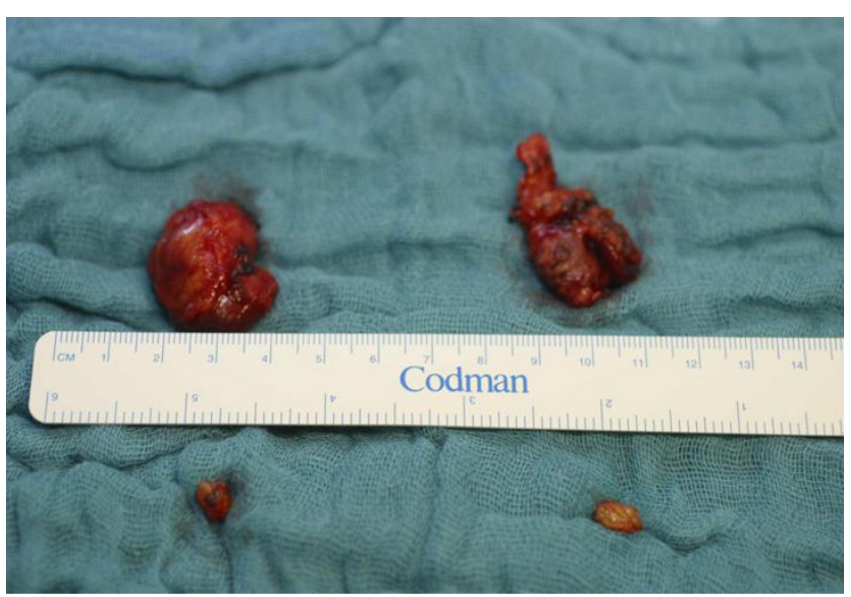

Figure 6

Macroscopic image of the tumor and removed lymph nodes.

scans occur in endemic goiter with or without thyroid autonomy [50]. Furthermore, it confirms recent reports indicating that a positive octreotide scan alone may not be sufficient to locate EAS [51]. In our patient, the octreotide scan was also weakly positive in an abdominal area not very typical for an ACTH-producing endocrine tumor that later on, however, proved to be the cause for EAS. Similarly, an ${ }^{111}$ In-pentetreotide scan provided the decisive clue for locating a malignant ACTH-producing tumor of the ileum in a patient reported by Segu et al. [15]. This suggests that patients with EAS and a positive octreoscan in locations atypical for an ACTH-producing tumor may benefit from explorative surgery using ${ }^{111}$ In-pentetreotide and a gamma probe.

Complicating the management of our patient with EAS and clearcut negative IPSS, a small lesion of the neurohypophysis was demonstrated at first presentation and during 1-year follow-up. False-negative results of IPPS in patients who do have an ACTH-producing pituitary tumor are reported to occur in up to $13 \%$ (7/127) [52]. Given the increasingly difficult to control hypercortisolemia, the low risk of transsphenoidal surgery, and the recent findings of clinical researchers at the National Institutes of Health, where surgical removal of ACTHomas confined to the neurohypophysis resulted in remission of hypercortisolism in 12 patients [1], we decided to proceed with an exploration of the pituitary. However, in our case removal of the posterior lobe pituitary lesion did not result in remission of hypercortisolemia. These results re-emphasize the notion that a single positive imaging study may represent a falsely positive result, while more than one positive study in the same region may confirm a true ACTH-secreting lesion $[2,6]$. It also underscores that in patients with Cushing's syndrome, dynamic biochemical 

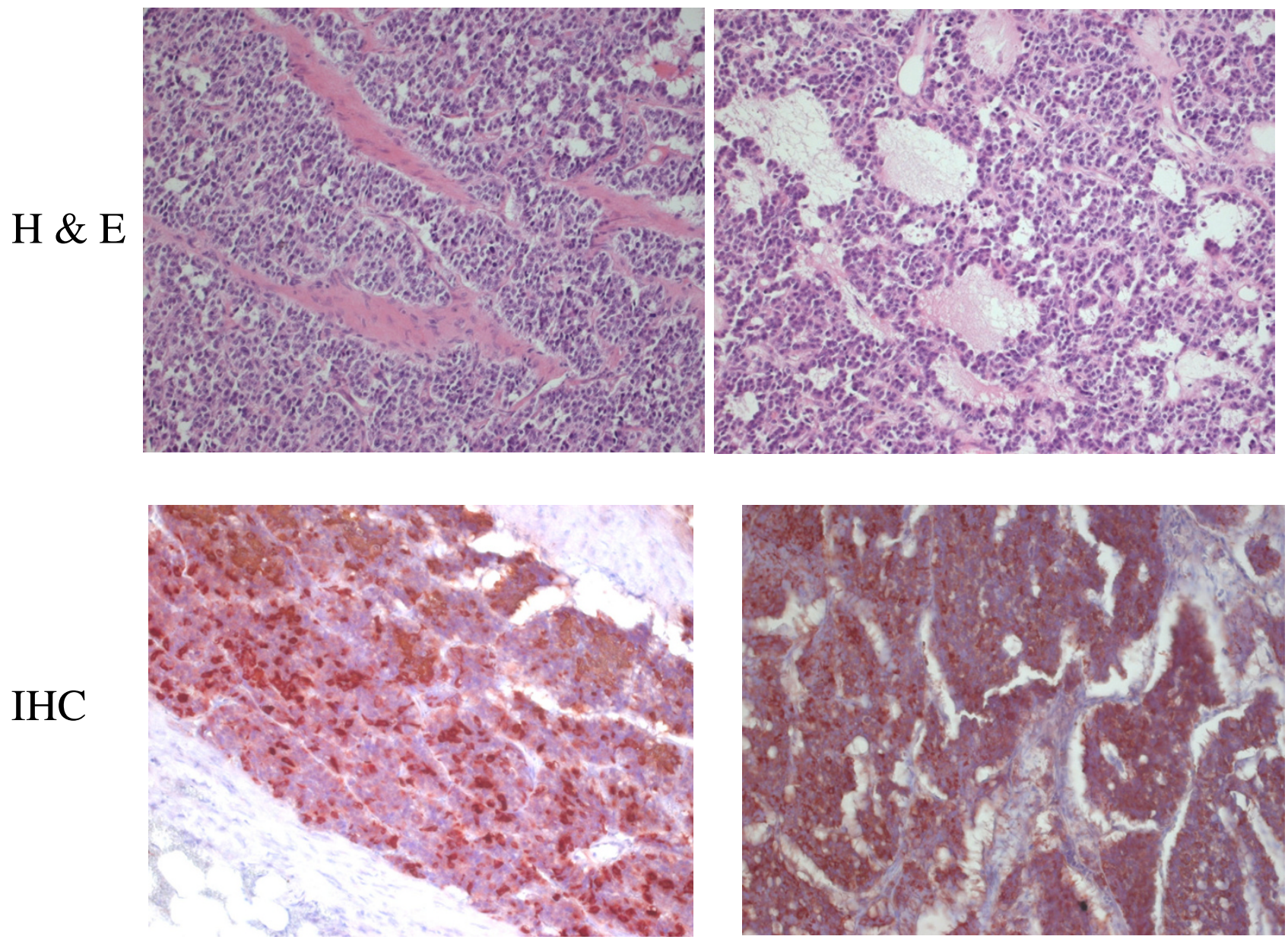

\section{Figure 7}

Images of histopathological Hematoxylin and Eosin stains and immunohistochemical ACTH expression.

testing is the most important step in establishing the diagnosis. Because our patient with EAS also had a left sided adrenal tumor in the setting of bilaterally enlarged adrenal glands, we measured 24 h urinary catecholamines including metanephrines to exclude an ACTH-producing pheochromocytoma which can occur in up to $25 \%$ of patients with EAS. In a recent study, 3 of 28 patients with ACTH-dependent Cushing's syndrome had focal adrenal nodules [53]. Although non-catecholamine secreting pheochromocytomas have been described [9,54], this is unlikely in our patient who had remission of hypercortisolism and ACTH production after the mesenterial tumor had been removed.

At 18-months after first presentation, another extensive diagnostic procedure was performed including CT scans of chest, abdomen, and pelvis, MRI head, octreotide scan, and ${ }^{18} \mathrm{~F}-\mathrm{FDG}$ PET. Here, tracer accumulation in projection of the upper and middle part of the right abdomen was detectable in the octreotide scan and PET, for the first time corresponding to a $21 \times 15 \mathrm{~mm}$ and $26 \times 15 \mathrm{~mm}$ tumor mass on CT and MRI scans, respectively. These results support the view that regular follow-up of occult EAS may result in localization of $\mathrm{ACTH}$ production at later time points due to tumor growth $[2,6]$. Furthermore, we could show that application of ${ }^{111}$ In-pentetreotide within hours before surgery facilitates localization of the tumor during surgery by use of radiolabeled ${ }^{111}$ In-pentetreotide and a gamma probe similar to recent reports $[55,56]$.

To further elucidate whether patients with neuroendocrine tumors that are (supposedly) completely resected, may benefit from adjuvant therapy including somatostatin analogs, we performed a MIB-1 proliferation index of the tumor in our patient and immunohistochemical analyses of somatostatin receptor expression [57,58]. We 
found all 5 somatostatin receptors negative using immunohistochemistry $[59,60]$. Especially the negative results for somatostatin receptor type 2 stand in contrast to our results on the octreoscans, although the tumor exceeded a size of $5 \mathrm{~mm}$ which is usually regarded as the detection limit for an octreoscan. These results may indicate that this ACTH-producing neuroendocrine tumor is very heterogeneous and/or somatostatin receptors were downregulated/saturated by intraoperative exposure to high doses of ${ }^{111}$ In-pentetreotide. Unfortunately, we were not able to assess mRNA for somatostatin receptor expression.

\section{Conclusion}

We report for the first time a patient with EAS due to a neuroendocrine carcinoma of the mesentery. This case not only may help elucidate the pathogenesis of (ACTHproducing) endocrine tumors, but also illustrates diagnostic pitfalls in the management of patients with EAS, and suggests that patients with EAS and an octreoscan positive in atypical locations may benefit from explorative radioguided surgery using a gamma probe.

\section{Abbreviations}

CT - computed tomography; EAS - ectopic ACTH-secretion; FDG - fluorodeoxyglucose; IPSS - inferior petrosal sinus sampling; MRI - magnetic resonance imaging; PET - positron emission tomography

\section{Competing interests}

Novartis Pharma GmbH will carry the costs of the articleprocessing charge in conjunction with a grant provided to Prof. Koch (CAK) on the topic "Neuroendocrine tumors: Nachuntersuchung aller operierten (R0/komplett resezierten) Patienten mit gastroenteropankreatischen neuroendokrinen Tumoren mittels Octreoscan". The authors declare that they have no other competing interests.

\section{Authors' contributions}

MF provided clinical care for this patient and drafted the paper. TL provided clinical care for this patient and helped draft and interpret the results, especially of studies related to nuclear medicine. HW provided clinical care for this patient and operated on the patient. RK provided clinical care for this patient and helped draft and interpret the results, especially of studies related to nuclear medicine. AT provided important insights into the histopathological diagnosis of this patient, delivered macroscopic, microscopic, and immunohistochemical images of this patient's tumor, and helped interpret the results. MM provided clinical care for this patient and helped interpret radiological images performed in this patient. MB conducted transsphenoidal surgery in this patient and helped interpret the clinical course and results of various tests. SP carried out immunohistochemical studies on somatostatin receptor types and helped interpret the results and draft the paper. JK delivered important insights into the laboratory and clinical chemistry aspects of this patient's history. RP helped interpret the results of all studies performed in this patient and provided intellectual input. CAK designed this study, interpreted the results, drafted the paper, and finalized the manuscript after input from the other authors.

All authors read and approved the final version of the manuscript.

\section{Acknowledgements}

We thank all physicians and nurses who were involved in the clinical care for this patient. We thank especially Drs. A.O.Vortmeyer and E.H. Oldfield at the National Institutes of Health, Bethesda, MD, for offering their help in managing this patient. We also thank Novartis Pharma GmbH for supporting Dr. Koch in his efforts in elucidating the pathogenesis of neuroendocrine tumors. The antibodies for immunhistochemical detection of somatostatin receptors were kindly provided by Stefan Schulz.

\section{References}

I. Weil RJ, DeVroom HL, Vortmeyer AO, Nieman LK, Oldfield EH: Adenomas Confined to the Neurohypophysis in Cushings Disease. Endocrine Society Meeting San Diego CA 2005:P2-526.

2. Wajchenberg BL, Mendonca BB, Liberman B, Pereira MA, Carneiro PC, Wakamatsu A, Kirschner MA: Ectopic adrenocorticotropic hormone syndrome. Endocr Rev 1994, I 5:752-787.

3. Phan GY, Yeo CJ, Hruban RH, Lillemoe KD, Pitt HA, Cameron JL: Surgical experience with pancreatic and peripancreatic neuroendocrine tumors: review of 125 patients. J Gastrointest Surg 1998, 2:472-482.

4. Koch CA, Doppman JL, Watson JC, Patronas NJ, Nieman LK: Spinal epidural lipomatosis in a patient with the ectopic corticotropin syndrome. N Engl J Med 1999, 34 I: I399-I400.

5. Aniszewski JP, Young WF, Thompson GB, Grant CS, van Heerden JA: Cushing syndrome due to ectopic adrenocorticotropic hormone secretion. World J Surg 200I, 25:934-940.

6. Ilias I, Torpy DJ, Pacak K, Mullen N, Wesley RA, Nieman LK: Cushing's syndrome due to ectopic corticotropin secretion: twenty years' experience at the National Institutes of Health. J Clin Endocrinol Metab 2005, 90:4955-4962.

7. Doppman JL, Nieman LK, Cutler GB Jr, Chrousos GP, Fraker DL, Norton JA, Jensen RT: Adrenocorticotropic hormone-secreting islet cell tumors: are they always malignant ? Radiology 1994, 190:59-64.

8. Mure A, Gicquel C, Abdelmoumene N, Tenenbaum F, Francese C, Travagli JP, Gardet P, Schlumberger M: Cushing's syndrome in medullary thyroid carcinoma. I Endocrinol Invest 1995, I 8:180-185.

9. Alvarez P, Isidro L, Gonzales-Martin M, Loidi L, Arnal F, Cordido F: Ectopic adrenocorticotropic hormone production by a noncatecholamine secreting pheochromocytoma. J Urol 2002, | 67:25|4-25I5.

10. Smallridge RC, Bourne K, Pearson BW, van Heerden JA, Carpenter $P C$, Young WF: Cushing's syndrome due to medullary thyroid carcinoma: diagnosis by proopiomelanocortin messenger ribonucleic acid in situ hybridization. J Clin Endocrinol Metab 2003, 88:4565-4568.

II. Miehle K, Tannapfel A, Lamesch P, Borte G, Schenker E, Kluge R, Ott RA, Wiechmann V, Koch M, Kassahun W, Paschke R, Koch CA: Pancreatic neuroendocrine tumor with ectopic adrenocorticotropin production upon second recurrence. J Clin Endocrinol Metab 2004, 89:373|-3736.

12. Bankole DO, Bertino JR, Cyne EA, Coonce M: Ectopic Cushing's syndrome in cloagenic carcinoma of the anal canal: a case demonstrating APUD characteristics. Yale J Biol Med 1980, 53:543-553.

13. Anthoney DA, Dunlop DJ, Connell JM, Kaye SB: Colonic adenocarcinoma associated ectopic ACTH secretion: a case history. Eur J Cancer 1995, 3 I A:2 109-2 II 2. 
14. Dobnig H, Stepan V, Leb G, Wolf G, Buchfelder M, Krejs G]: Recovery from severe osteoporosis following cure from ectopic ACTH syndrome caused by an appendix carcinoid. J Intern Med 1996, 239:365-369.

15. Segu VB, Mahvi DM, Wilson MA, Hale SJ, Warner TF, Meredith M, Shenker Y: Use of In-I I I pentetreotide scintigraphy in the diagnosis of a midgut carcinoid causing Cushing's syndrome. Eur J Endocrinol 1997, I37:79-83.

16. Uecker JM, Janzow MT: A case of Cushing syndrome secondary to ectopic adrenocorticotropic hormone producing carcinoid of the duodenum. Am Surg 2005, $71: 445-446$.

17. Valo I, Rohmer V, Guyetant S, Martin JF, Venault S, Saint-Andre JP: Cushing's syndrome caused by a well-differentiated ileal neuroendocrine carcinoma. Endocr Pathol 2000, I I:359-364.

18. Onishi R, Sano T, Nakamura Y, Namiuchi S, Sawada S, Ihara C, Shimatsu A: Ectopic adrenocorticotropin syndrome associated with undifferentiated carcinoma of the colon showing multidirectional neuroendocrine, exocrine, and squamous differentiation. Virchows Arch 1996, 427:537-541.

19. Hashi A, Yasmizu T, Yoda I, Kou T, Mizuno K, Hirata S, Kato J, Katoh $R$, Inoue $M$, Kawaguchi A, Nakazato M, Onaya $T$ : A case of small cell carcinoma of the uterine cervix presenting Cushing's syndrome. Gynecol Oncol 1996, $61: 427-431$.

20. Orbetzova $M$, Andreeva $M$, Zacharieva S, Ivanova $R$, Dashev $G$ : Ectopic ACTH-syndrome due to ovarian carcinoma. Exp Clin Endocrinol Diabetes 1997, I 05:363-365.

2I. Solcia E, Kloppel G, Sobin LH: Histological typing of endocrine tumours. 2nd edition. Springer, Berlin, Heidelberg, New York; 2000.

22. DeBold CR, Menefee JK, Nicholson WE, Orth DN: Proopiomelanocortin gene is expressed in many normal human tissues and in tumors not associated with ectopic adrenocorticotropin syndrome. Mol Endocrinol 1998, 2:862-870.

23. Vortmeyer AO, Lubensky IA, Merino MJ, Wang CY, Pham T, Furth $\mathrm{EE}$, Zhuang Z: Concordance of genetic alterations in poorly differentiated colorectal neuroendocrine carcinomas and associated adenocarcinomas. J Natl Cancer Inst 1997, 89:|448-53.

24. Arita-Melzer O, Medina H, Borsotto G, Gamboa A, Larriva-Sahd J, Trejo G, Cardenas S, Aguilar-Salinas CA, Rull JA, Gomez-Perez FJ: An ectopic adrenocorticotropic hormone syndrome caused by a sacrococcygeal chordoma: report of a case with a slow progression. Endocr Pract 1998, 4:37-40.

25. Arioglu E, Gottlieb NA, Koch CA, Doppman JL, Grey NJ, Gorden P: Natural history of a proinsulin-secreting insulinom: from symptomatic hypoglycemia to clinical diabetes. I Clin Endocrinol Metab 2000, 85:3628-3630.

26. Witzigmann H, Loracher C, Geissler F, Wagner T, Tannapfel A, Uhlmann D, Caca K, Hauss J, Hehl JA: Neuroendocrine tumours of the duodenum. Clinical aspects, pathomorphology, and therapy. Langenbeck's Arch Surg 2002, 386:525-533.

27. Pelte MF, Schwaller J, Cerrato C, Meier CA: Proopiomelanocortin expression in a metastatic breast carcinoma with ectopic ACTH secretion. Breast / 2004, 10:350-354.

28. Yu J, Koch CA, Patsalides A, Chang R, Altemus RM, Nieman LK, Pacak $\mathrm{K}$ : Ectopic Cushing's syndrome caused by an esthesioneuroblastoma. Endocr Pract 2004, 10:119-124

29. Koch CA, Azumi N, Furlong MA, Jha RC, Kehoe TE, Trowbridge $\mathrm{CH}$, O'Dorisio TM, Chrousos GP, Clement SC: Carcinoid syndrome caused by an atypical carcinoid of the uterine cervix. J Clin Endocrinol Metab 1999, 84:4209-4213.

30. Koch CA, Brouwers FM, Rosenblatt K, Burman KD, Davis MM, Vortmeyer AO, Pacak K: Adrenal ganglioneuroma in a patient presenting with severe hypertension and diarrhea. Endocr Rel Cancer 2003, 10:99-107.

31. Koch CA, Rodbard JS, Brouwers FM, Eisenhofer G, Pacak K: Hypotension in a woman with metastatic dopamine-secreting carotid body tumor. Endocr Pract 2003, 9:310-3|4.

32. Koch CA, Pacak K, Chrousos GP: Endocrine Tumors. In Principles and practice of pediatric oncology 5th edition. Edited by: Pizzo P \& Poplack DG. Lippincott Williams \& Wilkins, Philadelphia, PA; 2005

33. Koch CA, Rother KI, Roth J: Tumor hypoglycaemia linked to IGF-II. In Contemporary Endocrinology: The IGF System Edited by: Rosenfeld R, Roberts C. Humana Press Inc, Totowa, NJ; 1999:675-698.

34. LeRoith D: Tumor-induced hypoglycaemia. N Engl J Med 1999, 34I:757-758.
35. Nieukoop PD: Pattern formation in artificially activated ectoderm. Dev Biol 1963, 7:255-279.

36. Maire F, Couvelard A, Vullierme MP, Kianmanesh R, O'Toole D, Hammel P, Belghiti J, Ruszniewski P: Primary endocrine tumours of the liver. Br J Surg 2005, 92: I 255-1260

37. Yang L, Li S, Hatch H, Ahrens K, Cornelius JG, Petersen BE, Peck AB: In vitro trans-differentiation of adult hepatic stem cells into pancreatic endocrine hormone-producing cells. Proc Natl Acad Sci USA 2002, 99:8078-8083.

38. Perrier ND, Batt KP, Thompson GB, Grant CS, Plummer TB: An immunohistochemical survey for neuroendocrine cells in regional pancreatic lymph nodes: a plausible explanation for primary nodal gastrinomas ? The Mayo Clinic Pancreatic Surgery Group. Surgery 1995, I I 8:957-965

39. Arnaldi G, Angeli A, Atkinson, Bertagna X, Cavagnini F, Chrousos GP, Fava GA, Findling JW, Gaillard RC, Grossman AB, Kola B, Lacroix A, Mancini T, Mantero F, Newell-Price J, Nieman LK, Sonino N, Vance ML, Giustina A, Boscaro M: Diagnosis and complications of Cushing's syndrome: a consensus statement. J Clin Endocrinol Metab 2003, 88:5593-5602.

40. Raff H, Findling JW: A physiological approach to diagnosis of the Cushing's syndrome. Ann Intern Med 2003, I 38:980-99I.

4I. Isidori AM, Kaltsas GA, Pozza C, Frajese V, Newell-Price J, Reznek $\mathrm{RH}$, Jenkins PJ, Monson JP, Grossman AB, Besser GM: The ectopic adrenocorticotropin syndrome: clinical features, diagnosis, management, and longterm follow-up. I Clin Endocrinol Metab 2006, $91: 371-377$

42. Findling JW, Tyrrell JB: Occult ectopic secretion of corticotropin. Arch Intern Med 1986, I 46:929-933.

43. Pacak K, Eisenhofer G, Goldstein DS: Functional imaging of endocrine tumors: role of positron emission tomography. Endocr Rev 2004, 25:568-580.

44. Pacak K, Ilias I, Chen CC, Carrasquillo JA, Whatley M, Nieman LK: The role of I8F-FDG positron emission tomography and I II-In-pentetreotide scintigraphy in the localization of ectopic adrenocorticotropin-secreting tumors causing Cushing's syndrome. I Clin Endocrinol Metab 2004, 89:22 |4-222I.

45. Biering H, Pirlich M, Bauditz J, Sandrock D, Lochs H, Gerl H: PET scan in occult ectopic ACTH syndrome: a useful tool? Clin Endocrinol 2003, 59:404-405.

46. Bombardieri E, Maccauro M, De Deckere E, Savelli G, Chiti A: Nuclear medicine imaging of neuroendocrine tumours. Ann Oncol Suppl 200I, 2:S5I-6I.

47. Kaltsas G, Rockall A, Papadogias D, Reznek R, Grossman AB: Recent advances in radiological and radionuclide imaging and therapy of neuroendocrine tumours. Eur J Endocrinol 2004, | 5 | : | 5-27.

48. von Werder K, Muller OA, Stalla GK: Somatostatin analogs in ectopic corticotropin production. Metabolism I996, 45: I29-I3I.

49. Uwaifo GI, Koch CA, Hirshberg B, Chen CC, Hartzband P, Nieman LK, Pacak K: Is there a therapeutic role for octreotide in patients with ectopic Cushing's syndrome? J Endocrinol Invest 2003, 26:710-717.

50. Becker W, Schrell U, Buchfelder M, Hensen J, Wendler J, Gramatzki $M$, Wolf $F$ : Somatostatin receptor expression in the thyroid demonstrated with I I I In-octreotide scintigraphy. Nuklearmedizin 1995, 34:100-103.

5I. Krakoff J, Koch CA, Calis KA, Alexander RH, Nieman LK: Use of a parenteral propylene glycol-containing etomidate preparation for the long-term management of ectopic Cushing' s syndrome. J Clin Endocrinol Metab 2001, 86:4 I04-4108.

52. Swearingen B, Katznelson L, Miller K, Grinspoon S, Waltman A Dorer DJ, Klibanski A, Biller B: Diagnostic errors after inferior petrosal sinus sampling. I Clin Endocrinol Metab 2004, 89:3752-3763.

53. Imaki T, Naruse M, Takano K: Adrenocortical hyperplasia associated with ACTH-dependent Cushing's syndrome: comparison of the size of adrenal glands with clinical and endocrinological data. Endocr J 2004, 5 I:89-95.

54. Walther MM, Reiter R, Keiser HR, Choyke PL, Venzon D, Hurley K Gnarra JR, Reynolds JC, Glenn GM, Zbar B, Linehan WM: Clinical and genetic characterization of pheochromocytoma in von Hippel-Lindau families: comparison with sporadic pheochromocytoma gives insight into natural history of pheochromocytoma. J Urol 1999, 1 62:659-664. 
55. Filippi L, Valentini FB, Gossetti B, Gossetti F, De Vincentis G, Scopinaro F, Massa R: Intraoperative gamma probe detection of head and neck paragangliomas with II I In-pentetreotide: a pilot study. Tumori 2005, 91:173-176.

56. Grossrubatscher E, Vignati F, Dalino P, Possa M, Belloni PA, Vanzulli A, Bramerio M, Marocchi A, Rossetti O, Zurleni F, Loli P: Use of radioguided surgery with [ I I IIn]-pentetreotide in the management of an ACTH-secreting bronchial carcinoid causing ectopic Cushing's syndrome. J Endocrinol Invest 2005, 28:72-78.

57. Janson ET, Oberg K: Neuroendocrine tumors-somatostatin receptor expression and somatostatin analog treatment. Cancer Chemother Biol Response Modif 2003, $21: 535-546$.

58. Plockinger U, Rindi G, Arnold R, Eriksson B, Krenning EP, de Herder WW, Goede A, Caplin M, Oberg K, Reubi JC, Nilsson O, Delle Fave G, Ruszniewski P, Ahlman H, Wiedenmann B: Guidelines for the diagnosis and treatment of neuroendocrine gastointestinal tumours. A consensus statement on behalf of the European Neuroendocrine Tumour Society (ENETS). Neuroendocrinology 2004, 80:394-424.

59. Unger N, Serdiuk I, Sheu SY, Walz MK, Schulz S, Schmid KW, Mann $K$, Petersenn S: Immunohistochemical determination of somatostatin receptor subtypes $I, 2,3,4$, and 5 in various adrenal tumors. Endocrine Res 2004, 30:93I-934.

60. Kristiansen MT, Rasmussen LM, Olsen N, Jorgenson JO: Ectopic ACTH syndrome: discrepancy between somatostatin receptor status in vivo and ex vivo, and between immunostaining and gene transcription for POMC and CRH. Horm Res 2002, 57:200-204.

\section{Pre-publication history}

The pre-publication history for this paper can be accessed here:

http://www.biomedcentral.com/1471-2407/6/108/pre pub

Publish with Bio Med Central and every scientist can read your work free of charge

"BioMed Central will be the most significant development for disseminating the results of biomedical research in our lifetime. "

Sir Paul Nurse, Cancer Research UK

Your research papers will be:

- available free of charge to the entire biomedical community

- peer reviewed and published immediately upon acceptance

- cited in PubMed and archived on PubMed Central

- yours - you keep the copyright

Submit your manuscript here:

http://www.biomedcentral.com/info/publishing_adv.asp
BiolMedcentral 